\title{
PROSPEK DAN HAMBATAN BISNIS ASURANSI UMUM PERSPEKTIF HUKUM ISLAM
}

\author{
Abbas Arfan \\ Fakultas Syari'ah UIN Maliki Malang \\ Telepon: (0341) 559399 \\ e-mail:arfanbaraja@yahoo.com
}

\begin{abstract}
Majority of Indonesians have not made use of insurance as a means of protecting life, family and property from unforeseen events befalling on them. They are still unfamiliar with insurance and neither awared of types of insurance products available. Besides, their understanding about insurance law from Islamic legal perspective is far from enough. This article aims to reveal the importance of insurance in protecting people's life, family and property, and divergent opinions of ulama on the legal status of insurance.

Masyarakat Indonesia masih belum memanfaatkan keberadaan perusahan asuransi sebagai sarana melindungi diri, keluarga dan harta benda dari kejadian-kejadian tak terduga yang datang menimpa. Masyarakat kita masih sangat awam dengan asuransi dan belum banyak mengenal jenis-jenis produk asuransi yang tersedia. Di samping itu, pemahaman mayoritas umat Islam Indonesia tentang hukum asuransi dalam pandangan Hukum Islam (Fiqh) masih belum utuh. Artikel ini berusaha mengungkap pentingnya asuransi dalam melindungi
\end{abstract}

Keywords: Asuransi, Produk Asuransi, Hukum Islam.

\section{Pendahuluan}

Budi terduduk lesu di teras rumahnya. Wajahnya tampak bermuram durja; sedih memikirkan mobilnya yang hilang disaat parkir di sebuah pasar swalayan beberapa waktu lalu. Padahal, mobil tersebut merupakan satusatunya kendaraan yang dimiliki oleh keluarga. Akibat kejadian ini aktivitas keluarga jadi tertanggu. Walau Budi sudah melaporkan kejadian ini ke Polisi, namun belum ada kabar beritanya. Kemudian ia mulai berpikir, mengapa saya tidak membeli asuransi kendaraan bermotor?

Lain lagi yang dialami dengan Asep. Asep adalah seorang Pegawai Negeri Sipil (PNS) di kota Malang Jawa Timur. Asep sudah menikah dan sudah dikarunia satu orang anak lucu yang masih balita. Kejadian ini tidak diduga-duga datangnya. Kebakaran terjadi di suatu malam menjelang pagi, dimana keluarga Asep sedang lelap tertidur. Karena antara rumah satu dengan yang lainnya saling berdempetan maka nyala api sangat cepat menjalar hampir ke semua rumah di sekitarnya. Dalam waktu yang singkat, lebih 25 rumah terbakar habis, termasuk rumah Asep dan keluarga. Pemadam kebakaran tidak dapat berbuat banyak untuk segera memadamkan api, karena sempitnya jalan masuk dan lainnya. Keesokan harinya, Asep hanya bisa duduk termangu, melihat rumahnya sudah rata dengan tanah. Hasil jerih payahnya bekerja selama kurang lebih 15 tahun habis terbakar. Dalam kesedihannya, Asep berpikir, mengapa dulu saya tidak membeli asuransi kebakaran?. Memang dulu ia sempat mau mengambil asuransi rumah, namun niatnya itu dimentahkan oleh salah seorang Ustadz di 
kampungnya -yang diyakini luas ilmu agamanya itu- yang berpendapat haram hukumnya asuransi dengan tanpa menjelaskan dasar dan alasannya, apalagi menyebutkan beberapa perbedaan pendapat ulama kontemporer tentang hukum asuransi.

Cerita-cerita sedih seperi ini masih sering kita dengar terjadi di masyarakat. Kejadian-kejadian seperti ini, seperti kehilangan akibat pencurian, kebakaran, sakit dan membutuhkan dana yang besar dan lain- lain sering kali mengancam kesejahteraan dan kelangsungan keluarga. Ironinya, hal ini terjadi disaat berbagai program penjaminan dan perlindungan lewat jasa asuransi telah tersedia.

Masyarakat Indonesia masih belum memanfaatkan keberadaan perusahan asuransi sebagai sarana melindungi diri dan keluarga serta harta benda dari kejadian-kejadian tak terduga yang datang menimpa. Semestinya, kasus-kasus seperti contoh diatas tidak perlu terjadi bila mereka melakukan proteksi. Budi tidak harus kehilangan mobilnya bila ia tidak lupa mengasuransikan mobilnya. Begitu juga dengan Asep tak perlu sedih dan bingung karena rumah tempat ia dan keluarga tempati tidak harus habis terbakar dan tidak dapat dibangun kembali karena kebutuhan dana yang besar dapat dilindungi dengan mengasuransikan rumah tersebut terhadap kebakaran. Tapi, realitanya, masyarakat kita masih sa-ngat awam dengan asuransi dan belum ba-nyak mengenal jenis-jenis produk asuransi yang tersedia. Belum lagi, ditambah dengan pemahaman sebagain besar umat Islam Indonesia yang merupakan mayoritas pemeluk agama di Indonesia- yang setengah-setengah atau tanggung tentang hukum asuransi dalam pandangan ajaran Islam. Hal itu lebih didasarkan pada opini umum umat Islam Indonesia dan ulamanya bahwasanya hukum asuransi adalah haram secara mutlak.

Oleh karena itu, penulis tergugah untuk menulis artikel ini yang diberi judul Prospek dan Hambatan Bisnis Asuransi Umum Perspektif Hukum Islam, dengan rumusan masalah sebagai berikut: 1). Bagaimana Prospek Bisnis Asuransi Umum di Indonesia?, 2). Bagaimana Hukum Asuransi dalam Perspek- tif Islam? Dan 3). Apa Hambatan Bisnis Asuransi Umum di Indonesia dan Solusinya?

\section{Definisi Asuransi Umum dan Manfaatnya.}

Asuransi kerugian atau asuransi umum (general insurance) merupakan penanggulangan risiko atas kerugian, kehilangan manfaat dan tanggung jawab hukum kepada pihak ketiga yang timbul dari peristiwa yang tidak pasti. Penjaminan ini bersifat jangka pendek (short term), biasanya selama satu tahun. Sedangkan Asuransi jiwa memberikan jasa dalam penanggulan risiko yang dikaitkan dengan hidup atau meninggalnya seseorang yang dipertanggungkan dan bersifat jangka panjang (long term). Sesuai dengan ketentuan UU No. 2 Tahun 1992 tentang usaha perasuransian, masing-masing bid ang asuransi dikelola oleh perusahaan yang berbeda, tetapi beberapa produk asuransi, seperti asuransi kesehatan dan asuransi kecelakaan diri, dapat dikelola oleh perusahaan asuransi kerugian maupun jiwa. ${ }^{1}$

Asuransi banyak memiliki manfaat yang luas dan kompleks (secara mikro dan makro). Asuransi adalah sebuah ekosistem perputaran ekonomi simbiosis antar pelaku ekonomi (simbiosis mutualisme). Disebut simbiosis karena selain mampu memberikan perlindungan dan jaminan pada nasabah, asuransi juga menawarkan berbagai manfaat, misalnya meminimalisasi terjadinya risiko. Umumnya, perusahaan asuransi memiliki tim survei yang sudah berpengalaman sehingga mereka dapat memberikan rekomendasi untuk memperkecil terjadinya risiko terhadap kepentingan yang diasuransikan. Asuransi juga bisa berfungsi sebagai tabungan. Hal ini tampak dalam manfaat yang ditawarkan oleh asuransi jiwa. Pada dasarnya, hasil yang diterima pada akhir masa jatuh tempo merupakan kumpulan dari tabungan premi ditambah dengan bunga. Yang harus dingat, dari sudut pandang bisnis, perusahaan asuransi bukan merupakan perusahaan investasi sehingga bunga yang ditawarkan biasanya lebih rendah dari bunga deposito atau tabungan.

1 "Menunggu Arsitektur Perasuransian Indonesia", Majalah Human Capital No. 15 Juni 2005 
Disamping memberikan manfaat pada nasabah, asuransipun secara tidak langsung memberikan manfaat bagi para pelaku bisnis yang sudah pasti membutuhkan kredit dari bank untuk modal usahanya, karena premipremi yang dibayar oleh para nasabah asuransi akan disimpan oleh perusahaan-perusahan asuransi pada bank-bank nasional dalam bentuk deposito atau lainnya. Kemudian, uang yang sudah terkumpul itu, baik dari nasabah bank secara personal atau perusahaan, dikreditkan oleh pihak bank kepada para pengusaha.

Tidak semua dana asuransi itu di simpan di bank-bank lokal, karena banyak juga yang disimpan lagi dalam bentuk asuransi di luar negeri. Asosiasi Asuransi Umum Indonesia (AAUI) mencatat, tidak kurang dari 50\% total premi perusahaan asuransi umum/kerugian nasional pertahun direasuransikan ke berbagai perusahaan asuransi di luar negeri, akibatnya penerimaan premi asuransi nasional berkurang cukup signifikan.

\section{Prospek Bisnis Asuransi Umum}

Departemen Keuangan (Depkeu) optimis bahwa pertumbuhan premi perusahaan asuransi nasional sejak 2005 akan terus meningk at seiring dengan meningkatnya kebutuhan masyarakat terhadap asuransi. Data Depkeu menunjukkan pertumbuhan rata-rata industri asuransi selama empat tahun terakhir yang mencapai $20 \%$ setiap tahunnya. Perputaran roda perekonomian, baik dari segi investasi maupun pembangunan nasional yang terus menunjukkan perubahan, sangat berpengaruh terhadap peningkatan jumlah premi perusahaan asuransi Senada dengan itu, Frans Y. Sahusilawane, ketua Asosiasi Asuransi Umum Indonesia (AAUI) merasa optimistis dengan pertumbuhan asuransi. Menurutnya, potensi pasar asuransi masih sangat besar, karena masih sebagian kecil saja yang baru digarap selama ini. Ia juga yakin bahwa laju pertumbuhan ekonomi yang terus membaik akan semakin memperluas pangsa pasar asuransi. Namun menurut Hotbonar Sinaga, Ketua Dewan Asuransi Indonesia (DAI), pertumbuhan industri asuransi akan berkembang jika didukung regulasi dan pertumbuhan perekonomian yang membaik. Dia mengakui, perusahaan asuransi di Indonesia yang masih seumur jagung masih sangat rentan terhadap berbagai kebijakan baru yang dapat menghambat akselerasi pertumbuhan perusahaan asuransi. $^{2}$

Analisa di atas adalah analisa secara ekonomi. Dalam pandangan penulis, peningkatan itu terjadi karena tiga faktor penting berikut: pertama, meningkatnya kesadaran masyarakat akan pentingnya asuransi terutama asuransi umum. Kedua, giatnya promosi dari industri-industri asuransi umum di Indonesia, baik negeri atau swasta. Ketiga, banyaknya kecelakaan dan musibah yang terjadi di Indonesia, baik karena faktor alam atau kelalaian manusia.

Maka, jika kita cermati faktor pertama dan ketiga dapat menjadi alasan kuat untuk menjadikan industri asuransi, khususnya asuransi umum, sebagai bisnis andalan yang menjanjikan. Menurut analisa penulis faktor pertama lebih terkait dengan faktor sosiologis Indonesia, sementara faktor ketiga lebih dekat dengan faktor geografis.

Untuk konteks Indonesia, yang penduduknya berjumlah lebih-kurang 215 juta jiwa, jika perusahaan-perusahan asuransi itu bisa meningkatan kesadaran masyarakat akan penting dan manfaatnya asuransi, maka jumlah dana yang akan terkumpul dan berputar pada sektor ini sangat besar. Penetrasi ind ustri asuransi diperkirakan hanya sebesar maksimal $15 \%$ dari populasi Indonesia. Padahal, jika ditelusuri lebih jauh, penduduk yang memiliki polis atas nama sendiri maksimal baru 2\%; selebihnya diasuransikan oleh perusahaan.

Sedangkan untuk faktor ketiga, kondisi geografis Indonesia yang banyak memiliki gunung berapi, bisa memicu terjadinya musibah, seperti gempa vulkanik, gunung meletus, banjir bandang dan tanah longsor. Selain itu, sebagian besar wilayah Indonesia berada di lintasan patahan lempengan tektonik yang dapat menyebabkan gempa tektonik yang seringkali diiringi banjir tsunami. Semua bencana alam ini menghabiskan harta benda

${ }^{2}$ www.perbendaharaan.go.id (diakses 10 april 2009) 
dengan cepat dan seketika. Belum lagi jika ditambah musibah lain yang rutin tiap tahun di sebagian kota besar seperti Jakarta dan Surabaya, seperti banjir atau kebakaran. Sedangkan musibah karena manusia juga sering terjadi di Indonesia yang biasanya disebabkan oleh pertikaian dan konflik antar ras, suku, agama dan kelompok. Kondisi sosiologis bangsa Indonesia yang heterogen ini mampu menciptakan gesekan dan konflik yang sebetulnya tidak kita harapkan. Oleh karena itu, beragam musibah di tanah air ini ikut menciptakan kesadaran akan pentingnya asuransi umum, dan kesadaran ini akan semakin luas jika industri-industri asuransi umum bisa lebih meyakinkan masyarakat akan manfaat asuransi umum.

\section{Hukum Asuransi Perspektif Hukum Islam}

Hukum asuransi dalam perspektif hukum Islam yang dimaksud disini adalah perspektif para ulama, karena dalam dua sumber hukum Islam, al-Quran dan Sunah, tidak disebutkan kehalalan atau keharaman asuransi secara tersurat (tekstual), karena saat alQuran turun, belum ada industri asuransi (alta'min).

Menurut ulama Indonesia, hukum asuransi, baik asuransi jiwa atau umum, terbagi menjadi dua pendapat. Pendapat pertama diwakili oleh para ulama dari ormas Islam terbesar pertama di Indonesia, Nahdlatul Ulama (NU), yang berpendapat bahwa hukum asuransi adalah haram secara mutlak. Mereka berpendapat bahwa asuransi identik dengan judi, yang secara tegas diharamkan atas dasar al-Quran dan Sunah, dengan alasan karena bentuk transaksi perusahaan asuransi menyerupai kupon judi; para nasabah yang melakukan transaksi itu dijanjikan memperoleh sejumlah uang jaminan yang telah ditetapkan jika rumahnya terbakar misalnya, dengan syarat nasabah itu harus membayar premi selama menempati rumahnya. Dengan demikian, itu jelas merupakan judi murni, karena kedua belah pihak yang melakuakan transaksi pada dasarnya masing-masing tidak mengetahui siapa di antara mereka yang akan mem- peroleh keuntungan, sampai uang yang disepakati oleh keduanya diberikan. $^{3}$

Sedangkan pendapat kedua diwakili oleh para ulama dari ormas Islam terbesar kedua di Indonesia, Muhammadiyyah. Mereka berpendapat bahwa hukum asuransi adalah syubhat (samar-samar), karena tidak ada dalil syar'i yang secara jelas mengharamkan atau menghalalkan asuransi, baik asuransi umum atau jiwa. Konsekuensinya adalah bahwa umat Islam harus berhati-hati menghadapi asuransi dan baru diperbolehkan mengambil dan menggunakan asuransi dalam kondisi darurat (emergency) atau hajat/kebutuhan (necessity). ${ }^{4}$

Itu adalah pandangan ulama Indonesia, yang pada dasarnya tidak ada satupun dari dua kelompok di atas yang menghalalkan asuransi secara mutlak. Sedangkan di dunia Islam, khususnya ulama Timur Tengah, ada tiga perbedaan pendapat tentang hukum asuransi, yakni: ${ }^{5}$

Pertama, mereka yang mengharamkan asuransi secara mutlak dalam segala macam bentuknya yang ada sekarang ini, termasuk asuransi umum. Pendapat ini didukung oleh beberapa ulama antara lain, Sayid Sabiq, salah seorang ulama Mesir, Abdullah al-Qalqili, Mufti Yordania, Muhammad Yusuf al-Qardhawi, salah seorang ulama besar Mesir, yang sekarang tinggal di Qatar, dan Muhammad Bakhit al-Muth'i, mantan Mufti Mesir. Alasan mereka yang mengharamkan asuransi itu antara lain sebagai berikut:

a. Asuransi pada hakikatnya sama atau serupa dengan judi.

b. Mengandung unsur tidak jelas dan tidak pasti (uncertainty)

c. Mengandung unsur riba.

d. Mengandung unsur eksploitasi, ka rena pemegang polis akan mengalami kehilangan atau pengura-

3 Lebih lengkap lihat: "Solusi Problematika Aktual Hukum Islam; Keputusan Muktamar, Munas dan Kombes NU dari tahun 1926-1999" (Surabaya: Diantama, 2004), hlm. 307-311

4 Lihat: Masjfuk Zuhdi, "Masail Fiqhiyah" (Jakarta: CV Haji Masagung, 1994), hlm. 132-136.

${ }^{5}$ Ibid. 
ngan premi jika ia tidak bisa melanjutkan pembayaran preminya.

e. Premi-premi yang telah dibayarkan oleh para pemegang polis diputar dalam praktik riba (kredit berbunga) di bank konvensional.

f. Asuransi termasuk akad sharfi, yang disepakati keharamannya oleh para ulama, karena bentuknya sama dengan jual beli atau tukar menukar mata uang tidak dengan tunai (cash and carry).

g. Hidup dan mati, sakit dan musibah dijadikan objek bisnis yang berarti mendahului takdir Tuhan Yang Mahakuasa. ${ }^{6}$

Kedua, mereka yang membolehkan (menghalalkan) semua jenis asuransi yang ada. Pendapat ini didukung oleh beberapa ulama antara lain Abdul Wahab Khallaf, Guru Besar Syari'ah dan Usul Fiqh Universitas al-Azhar Kairo Mesir, Mustafa Ahmad Zarqa, Guru Besar Hukum Islam Fakultas Syariah Universitas Syria, Muhammad Yusuf Musa, Guru Besar Hukum Islam Universitas Kairo Mesir, dan Abdurrahman Isa, penulis al-Muamalat al-Haditsah wa Ahkamuha. Alasan mereka yang membolehkan asuransi termasuk asuransi umum dan jiwa antara lain adalah:

a. Tidak ada nash al-Quran dan hadis yang melarang asuransi.

b. Ada kesepakatan atau kerelaan kedua belah pihak.

c. Saling menguntungkan kedua belah pihak.

d. Mengandung maslahat 'ammah (kepentingan umum) karena premi-premi yang terkumpul bisa diinvestasikan untuk proyek-proyek yang produktif dan pembangunan.

e. Asuransi termasuk akad mudlarabah, artinya akad kerja sama bagi hasil antara pemegang polis (pemilik modal) dengan pihak perusahaan asuransi yang memutar modal atas dasar profit and loss sharing. (PLS).

${ }^{6}$ Sayid Sabiq, Fiqh al-Sunnah (Beirut Lebanon: Dar al-Fath, 1995) Ju z III, hlm. 301-304. f. Asuransi termasuk koperasi (syirkah ta'awuniyah).

g. Dapat diqiyaskan (analogi) dengan sistem pensiun, seperti Taspen.

Ketiga, mereka yang membolehkan asuransi yang bersifat sosial dan mengharamkan asuransi yang semata-mata bersifat komersial. Pendapat ini berada di tengahtengah antara dua pendapat di atas. Pendapat ini didukung oleh Muhammad Abu Zahrah, Guru Besar Hukum Islam Universitas Kairo Mesir. Alasan mereka membolehkan asuransi yang bersifat sosial pada garis besarnya sama dengan alasan pendapat kedua, sedangkan alasan yang mengharamkan asuransi yang bersifat komersial pada garis besarnya sama dengan alasan pendapat pertama.

Penulis sependapat dengan pandangan kedua yang menghalalkan seluruh macam asuransi, terutama asuransi umum atas dasar alasan sama dengan dalil yang digunakan kelompok kedua di tambah dengan sebuah pemahaman bahwa asuransi tidak sama dengan judi, karena asuransi bertujuan mengurangi resiko (reducing risks) dan bersifat sosial serta membawa kemaslahatan bagi diri dan keluarga, sementara judi justru mengandung risiko (creating risks), tidak bersifat sosial, dan membawa malapetaka bagi diri dan keluarga. Di samping itu, asuransi sudah diperhitungkan secara matematis untung ruginya bagi perusahaan asuransi dan bagi para pemegang polis, sehingga tidak ada pihak yang dirugikan secara mutlak.

\section{Hambatan Bis nis Asuransi Umum di Indo- nesia dan Solusinya.}

Dalam sebuah media disebutkan bahwa asurnasi umum di Indonesia tidak berkembang dengan baik dan Otoritas didesak segera mendisiplinkan pasar. Dalam analisanya disebutkan bahwa industri asuransi umum sedang mengalami krisis. Lambannya pertumbuhan premi berdampak pada perolehan laba. Total laba 92 asuransi umum di Indonesia sekitar Rp 1,8 triliun, hanya bertumbuh 0,02 persen dibandingkan tahun sebelumnya. Sebagai perbandingan, total laba 42 asuransi jiwa tumbuh 89 persen mencapai Rp 2,4 triliun. 
Untuk itu, peran serta pemerintah dalam memberikan dukungan terhadap industri pertumbuhan asuransi sangat dibutuhkan. Selain itu, dia berharap perusahaan asuransi tidak terpancing dengan perang tarif yang terjadi selama ini terjadi. Yang paling penting, perusahaan asuransi harus saling berlomba meningkatkan profesionalisme dalam melayani kepentingan nasabah. Dengan kata lain, perusahaan asuransi jangan hanya terjerumus memperebutkan pasar. ${ }^{7}$

Pertumbuhan premi asuransi umum pada tahun ini dan beberapa tahun kedepan diperkirakan masih di bawah 5 persen. Dan faktor yang menghambat pertumbuhan asuransi umum antara lain kond isi perekonomian yang belum memadai, bencana alam, dan kebijakan yang kurang kondusif. Gempa yang bertubi-tubi di penghujung tahun 2009 ini membuat klaim yang harus dibayar asuransi melonjak tajam. Dampaknya, laba asuransi menurun. Banyaknya korporasi yang kinerjanya menurun juga membuat permintaan asuransi menjadi rendah. Belum lagi otoritas kurang cepat dan tegas dalam menyelesaikan berbagai persoalan yang ada dalam industri asuransi umum, contohnya perang tarif premi yang berlangsung sejak dua tahun lalu belum juga reda sampai sekarang. Belum lagi harga premi yang ditawarkan sudah tidak rasional. Dengan premi yang sedemikian rendahnya, perusahaan asuransi bersangkutan dipastikan tidak bisa membayar saat terjadi klaim. Ini berarti dari awal mereka sudah tidak bertanggung jawab karena menarik premi dengan asumsi tidak akan terjadi klaim. Pada asuransi kendaraan bermotor misalnya, tarif premi bisa mencapai 1 persen. Padahal, normalnya sekitar 3 persen. Maka solusinya otoritas (pemerintah) harus bisa mendisiplinkan pasar. Dan untuk mencegah perang tarif berkelanjutan, pemerintah tidak perlu menetapkan standar tarif karena bisa melanggar undang-undang persaingan usaha. Yang perlu dilakukan pemerintah adalah menggiring agar penetapan tarif dilakukan secara rasional oleh setiap asuransi.

\footnotetext{
${ }^{7}$ www.ko mpas.com.
}

Direktur Asuransi Departemen Keuangan Isa Rachmatarwata ketika dikonfirmasi cukup kaget dengan data perkembangan asuransi umum. Dan ia mengelak dengan alasan belum mengecek datanya, maka belum bisa berkomentar. Dia juga belum bisa menjelaskan persoalan-persoalan yang bersarang dalam asuransi umum. Dan Frans Sahusilawane lebih jauh mengatakan, sebelum otoritas mampu mendisiplinkan pasar, lebih baik tidak perlu dulu menetapkan modal minimum. Karena jika modal ditambah, tapi kedisiplinan pasar dan ketegasan tidak ada, malah akan jadi bumerang. Dan kabarnya pemerintah berencana mewajibkan setiap asuransi memiliki modal minimum Rp 100 miliar pada akhir tahun 2009. Tapi AAUI menginginkan asuransi diberi waktu hingga 2013 untuk mencapai modal Rp 100 miliar. Dari 92 asuransi umum, terdapat 74 perusahaan yang modalnya di bawah Rp 100 miliar. ${ }^{8}$

Kapler Arifin Marpaung, Ketua Umum Asosiasi Broker Asuransi dan Reasuransi Indonesia yang juga Presiden Komisaris BGIB menilai kualitas pertumbuhan industri asuransi nasional masih belum bagus, baik dari sisi penetrasi maupun kontribusi terhadap Produk Domestik Bruto (PDB). Jumlah premi yang terkumpul setiap tahun baru sekitar 2\% dari PDB, sedangkan negara-negara lain sudah di atas rata-rata 10\%."Bahkan ada negara yang sudah mencapai kontribusi $40 \%$ dari PDB," tuturnya. Total aset industri asuransi nasional baru 4,8\% dari total aset lembaga keuangan di Indonesia. Dan khusus untuk asuransi kerugian (umum), Kapler menilai hanya $25 \%$ pemegang polis yang membeli asuransi berdasarkan kesadaran sendiri. Sisanya membeli asuransi kerugian karena adanya kontrak bisnis. Misalnya, seseorang harus mengasuransikan mobilnya karena mobil itu dibeli dari perusahaan pembiayaan kata tersebut. $^{9}$

Fakta lain dikemukakan oleh Ketua Dewan Asuransi Indonesia (DAI) Hotbonar Sinaga. la menyorot begitu besarnya ketimpangan dalam industri asuransi nasional, di mana dari sekitar 40 asuransi jiwa hanya 6

\footnotetext{
${ }^{8}$ Ibid.

${ }^{9}$ Majalah Hu man Capital No. 15.
} 
perusahaan yang menguasai $80 \%$ pangsa pasar asuransi jiwa. Begitu pula dengan industri kerugian (umum): dari sekitar 90 asuransi kerugian yang ada, sebanyak 14 perusahaan menguasai $80 \%$ pangsa pasar. Berdasarkan kondisi ini, ungkapnya, perlu dilakukan kategorisasi perusahaan asuransi sekaligus menyiapkan asuransi lokal menjadi pemain global. "Asuransi lokal seperti Jiwasraya dan Bumiputera telah memiliki aset triliunan rupiah. Mereka berpotensi menjadi pemain global," tukasnya. ${ }^{10}$

Pemerintah selama ini bukannya tidak berbuat untuk memajukan industri asuransi nasional, antara lain, dengan dikeluarkannya PP 63/1999 dan KMK 425/2003. Untuk menyehatkan perusahaan asuransi, diberlakukan ketentuan modal minimal $\mathrm{Rp} 100$ miliar untuk perusahaan asuransi yang baru berdiri. Bagi perusahaan lama dan belum memenuhi ketentuan modal ini diberlakukan ketentuan RBC (Risk Based Capital). Tahun lalu ketentuan RBC adalah $120 \%$. Bagi perusahaan yang tidak memenuhi ketentuan RBC diharuskan untuk menyuntik modal baru ataupun melakukan merger. Kenyataannya, masih banyak perusahaan yang tidak bisa menambah modal tetapi juga enggan melakukan merger. Pemerintah juga tidak mengambil tindakan tegas terhadap hal ini. Kondisi ini menyebabkan munculnya ketidakjelasan. ${ }^{11}$

Dalam hemat penulis, hal ini akan mengganggu industri asuransi juga. Kalau ada perusahaan asuransi yang bangkrut dan tidak mampu memenuhi kewajibannya, citra industri asuransi ikut rusak. Hal ini menghambat upaya mengembangkan pasar asuransi nasional. Dan sejalan dengan rencana menyusun Arsitektur Perasuransian Indonesia, maka perlu para pelaku industri asuransi nasional menjalankan komitmennya sesuai perjanjian dan melakukan kampanye nasional untuk membangun citra. Selama ini, masih ada perusahaan asuransi yang menolak klaim yang diajukan pemegang polis, kendati pun sudah difasilitasi oleh perusahaan broker asuransi. Alasannya berputar-putar, seakanakan broker pun tidak mengerti asuransi. Bila

\footnotetext{
${ }^{10}$ Ibid.

${ }^{11}$ Ibid.
}

broker yang mengerti asuransi saja diberlakukan begitu, bagaimana jadinya dengan pemegang polis biasa?. Walau memang kita tidak menafikan fakta adanya pemegang polis yang tidak bertanggung jawab. Tapi, tidak adil jika memandang semua pemegang polis demikian.

Di samping Hambatan dan hambatan bagi bisnis asuransi umum seperti tersebut di atas. Dalam analisa penulis, ada faktor penghambat lainnya, seperti sosiologi, kultur budaya dan agama yang dalam hal ini adalah agama Islam. Maka dapat disimpulkan bahwa ada dua faktor utama yang menghambat lancarnya bisnis asuransi umaum di Indonesia, yaitu: faktor internal (dari dalam tubuh perusahaan asuransi itu sendiri) dan faktor eksternal (dari luar; seperti masyarakat dan keyakinan/agama yang membentuknya dan juga pemerintah sebagai pembuat kebijakan).

Untuk faktor internal; Hambatan yang menghambat adalah datang dari perusahan asuransi itu sendiri dan kinerjanya yang kurang profesional dan tidak amanah; dengan sering ingkar janji dalam kesepakatan kontrak dengan nasabah terutama dalam hal pembayaran klaim atau minimal lama dan proses yang lama dalam proses pencairan klaim yang notabene menjadi hak pemilik polis dan kewajiban asuransi untuk membayarnya tepat waktu sesuai perjanjian.

Tingginya kasus penolakan klaim oleh perusahaan asuransi membuat perlindungan nasabah sebagai pihak konsumen semakin terabaikan. Syukurnya sudah ada badan mediasi yang bisa jadi solusi sementara. Badan Mediasi Asuransi Indonesia dibentuk sebagai mediator dalam menyelesaikan setiap kasus sengketa antara nasabah dengan perusahaan asuransi secara damai. Sejak beroperasi bulan September tahun 2004 sampai 2005 data dari Badan Mediasi Asuransi Indonesia (BMAI) telah menerima 70 kasus, 40 kasus di antaranya sudah diproses. Kasus penolakan klaim tersebut didominasi jenis asuransi jiwa. Dan alasan penolakan itu biasanya karena perusahaan menganggap informasi yang diberikan nasabah tidak sesuai dengan kenyataan atau pelanggaran berupa keterlambatan pembayaran premi. Maka akibat tingginya kasus peno- 
lakan klaim oleh perusahaan asuransi, membuat jasa asuransi mendapat sorotan tajam dari masyarakat dengan dampak merosotnya citra perusahaan asuransi karena dinilai mau menang sendiri yang berakibat pada tidak percayanya lagi masyarakat asuransi secara umum dan mayarakat enggan berhubungan lagi dengan asuransi.. Dan sebelum BMAI dibentuk, penyelesaian kasus sengketa antara nasabah dengan perusahaan asuransi banyak menggunakan jalur pengadilan dan arbitrase. Namun, langkah ini membutuhkan banyak biaya karena si nasabah harus menyewa pengacara. Belum lagi prosesnya yang terlalu rumit. . ${ }^{12}$ Bahkan keluhan soal klaim ini rupanya juga dialami oleh mantan Wakil Presiden M. Jusuf Kalla. Perusahaan asuransi pernah menolak klaim yang diajukan, dan untuk membereskannya butuh waktu lama. Sehinga saat membuka Kongres Asosiasi Asuransi Jiwa Indonesia di Istana Wapres 19 April 2005, beliau minta para pelaku industri untuk tidak mengembangkan kebiasaan menghindar ketika terjadi klaim. ${ }^{13}$

Dan solusi bagi Hambatan ini adalah bagaimana industri asuransi mau membenahi diri dan berupaya semaksimal mungkin memperbaiki citranya dengan langkah-langkah nyata dan kongkrit tertutama dalam masalah pembayaran klaim dengan mudah dan tepat waktu sesuai janji dan kesepakatan kontrak. Dan dana yang terkumpul berupa premi-premi yang dibayar oleh para pemegang polis kepada perusahaan asuransi, hendaknya dimanfaatkan untuk proyekproyek yang produktif dan pembangunan guna ikut menaikan citra posit if asuransi.

Adapun untuk faktor eksternal; Hambatan yang menghambat datang dari luar, yaitu pemerintah dan masyarakat. Hambatan dari pemerintah terbatas pada kebijakan-kebijakan yang dibuat pemerintah yang sering merugikan pihak asuransi dan menghambat lajunya bisnis asuransi. Maka solusi yang ditawarkan adalah sebaiknya pemerintah dalam membuat kebijakan yang terkait dengan asuransi harus melibatkan semau komponennya, seperti pi-

12 "Penolakan Klaim Perusahaan Asuransi Tinggi" www. ko mpas.com (diakses 10 April 2009)

${ }^{13}$ Majalah Human Capital No. 15. hak asuransi, perbankan dan masyarakat sebagai konsumen.

Adapun hambatan dari masyarakat Indonesia dapat disebabkan oleh beberapa kendala yang antara lain adalah sebagai berikut:

a. Kultur budaya; masyarakat indonesia adalah masyarakat yang kompleks dan heterogen. Dalam kultur budaya jawa misalnya cenderung menerima apa adanya atas segala macam masalah dan musibah. Mereka tidak mau nekoneko, sehingga mereka beranggapan bahwa mengasuransikan jiwa atau rumah misalnya sebagai sebuah tindakan yang menyalahi prilaku leluhur dan bertentangan dengan filisofi jawa. Belum lagi Sebagian besar mereka masih awam, kurang berpendidikan dan tinggal di pedesaan. Maka solusi yang harus diupayakan -walau butuh waktu lama dan dana besar- adalah dengan merubah masyarakat Indonesia dari pola pikir yang kuno dan tradisinal menjadi pola pikir modern dan rasional lewat jalur pendidikan formal atau non formal, seperti penyuluhan dan pengajian di majelis-majelis taklim. Atau minimal pemerintah dan industri-industri asuransi sering bersosialisasi ke masyarakat terutama kalangan menengah ke bawah dan pedesaan.

b. Agama; pemahaman masyarakat tentang agama, khususnya agama Islam yang belum lengkap dan sepotongpotong tentang hukum asuransi misalnya. Fatwa dari dua ormas besar Islam Indonesia, yaitu NU yang mengharamkan Asuransi dan Muhammadiyah yang mensubhatkan asuransi ini juga ikut andil besar dan bertanggungjawab dalam menghambat lajunya bisnis asuransi di tanah air ini. Maka solusinya adalah bagaimana merubah sebuah dogma haram tentang asuransi yang sudah mengeras dalam keyakinan sebagian besar umat Islam Indonesia ini atau paling tidak ada kejujuran dari para ulama kita untuk juga bisa menghargai pendapat ulama lain 
yang beda pendapat dan kemudian ditawarkan pada masyarakat luas agar mereka bisa menentukan pilihannya sendiri? Maka jawabannya antara lain dengan cara mendiskusikan ulang hukum asuransi antara para ulama yang berbeda pendapat ini secara terbuka di hadapan masyarakat luas dan MUI (Majelis Ulama Indonesia) yang di Pusat sebagai pembawa aspirasi umat Islam Indonesia, hendaknya segera mengeluarkan fatwa hukum asuransi, agar umat Islam di Indonesia mempunyai pandangan dan pegangan yang lebih mantap terhadap asuransi. Dan solusi lain adalah hendaknya pihak perusahaan asuransi mengadakan pembaharuan manajemen dan sistem asuransi dengan memperhatikan prinsip-prinsip dan jiwa syariat Islam dengan cara mendirikan Asuransi Syari'ah.

\section{Penutup}

Sebagai penutup dari tulisan ini, penulis akan menyimpulkan beberapa poin penting

\section{DAFTAR PUSTAKA}

Keputusan Muktamar, Munas dan Kombes NU dari tahun 1926-1999; "Solusi Problematika Aktual Hukum Islam". 2004. Surabaya: Diantama

Majalah Human Capital No. 15 Juni 2005 dan saran tentang prospek dan Hambatan bisnis asuransi umum di Indonesia, yaitu:

a. Bisnis asuransi kedepan akan mendapat prospek cerah dan menguntungan bahkan bisa menjadi gurita pengelola keuangan dan ekonomi di Indonsia dan dunia dengan syarat pihak industri asuransi bisa meyakinkan masyarakat luas tentang fungsi dan manfaat asuransi umum dan ia terus dan kontiyu meningkatkan kualitas kinerjanya dengan sungguh-sungguh dan kongkret.

b. Pemerintah bertindak adil sebagi wasit antara ind usri asuransi dan nasabah sebagai konsumen. Dan kebijakankebijakan pemerintah harus mampu mengakomodir keduanya.

c. Industri-industri asuransi mau membuka diri dengan menerima usulan dan masukan atau solusi dari pihak ketiga, seperti penulis ini. Dan mau melakukan solusi-solusi yang ditawarkan oleh penulis sebagai jalan keluar atas beberapa hambatan yang selama ini menghambat lajunya bisnis asuransi umum di Indonesia.

Sabiq, Sayid, 1995. Fiqh al-Sunnah. BeirutLebanon: Dar al-Fath

www.. Kotagaul.com

www.perbendaharaan.go.id

www.kompas.com

Zuhdi, Masjfuk. 1994. Masail Fiqhiyah. Jakarta: CV Haji Masagung 